\title{
Thalassinidean shrimps (Crustacea: Decapoda) from north-western Australia, including five new species
}

\author{
Gary C. B. Poore \\ Museum Victoria, GPO Box 666E, Melbourne, Victoria 3001 Australia. \\ email: gpoore museum.vic.gov.au
}

\begin{abstract}
Recent collections of Thalassinidea (Upogebiidae excluded) from the Dampier Archipelago, the North-West Shelf and the Timor Sea include few individuals of seven species of which five are new. Callianassa amboinensis de Man, 1888 (Callianassidae) and Spongiaxius brucei (Sakai, 1986) (Axiidae) are reported. The new species are: Bouvieraxius michelae sp. nov. and Paraxiopsis dianae sp. nov. (Axiidae); Biffarius melissae sp. nov. and Callianassa sahul sp. nov. (Callianassidae); and Michelea dampieri sp. nov. (Micheleidae). One family, two subfamilies and 22 thalassinidean genera additional to those listed by Poore (1994), plus recent synonymies are tabulated, bringing the number of families to 12 and genera to 95 .
\end{abstract}

\section{INTRODUCTION}

The Australian thalassinidean fauna is diverse, with 88 species listed by Davie (2002). Among the extensive marine collections made by dredge and diving around the Dampier Archipelago, Western Australia, as part of the Western Australian Museum-Woodside Energy Partnership, are several new species (Jones, 2004). Most of these are upogebiids, reported elsewhere (Ngoc-Ho, 2007). Of two callianassids, one is a new species. There is one specimen of a new micheleid and two of a new axiid. Specimens of a second axiid, already described, from the nearby North-West Shelf are also reported. A specimen of a second new axiid and one of a second new callianassid were found as part of a survey by Consulting Environmental Engineers of sediments surrounding shoals of the Sahul Bank, Timor Sea.

A key to families and genera (Poore, 1994) remains a good starting point for identifying species of Thalassinidea but does not include one of the genera recognised herein, nor one family, two subfamilies and another 21 genera erected since. These and recently proposed synonymies (Table 1) bring the number of families of Thalassinidea to 12 and genera to 95. Dworschak (2005) recognised 556 species. An interactive electronic key to thalassinidean families and genera in the INTKEY format has been constructed by the author and enabled species to be placed.

\section{MATERIAL AND METHODS}

Material is deposited in the Western Australian Museum, Perth (WAM) and Museum Victoria, Melbourne (NMV). Lengths are given as carapace length $(\mathrm{cl})$ and total length $(\mathrm{tl})$; ovigerous is abbreviated as ovig. Rows of setae on the margins of limbs of callianassids are generally not figured.

\section{Family Axiidae Huxley, 1879}

\section{Remarks}

Axiids are usually most easily recognised by the toothed, flattened rostrum and this is the case for the three species described here. For a modern family diagnosis see Poore (1994).

\section{Bouvieraxius Sakai and de Saint Laurent, 1989}

Bouvieraxius Sakai and de Saint Laurent, 1989: 45. - Sakai, 1992a: 165-166.

Posthonocaris Kensley, 1989: 964.

\section{Remarks}

Species of Bouvieraxius are defined by the combination of uropodal exopod with a transverse suture, pereopodal epipods present, three pairs of pleurobranchs (hidden by larger arthrobranchs), rostrum broad and toothed, pleopods $2-5$ with appendix interna, male pleopod 1 present and a prominent scaphocerite (Sakai and de Saint Laurent, 1989; Sakai, 1992a; Poore, 1994). Four species have been described, three from the IndoWest Pacific and one from Barbados (Kensley, 1996b). The type locality of the type species, B. rudis (Rathbun, 1906), is in Hawaii. Michele de Saint Laurent drew my attention in 1990 to differences between Sakai's drawings of the Hawaiian holotype (in Sakai and de Saint Laurent, 1989: fig. 12) and the specimen from Madagascar (figs 13, 14). She concluded that neither the individual from Madagascar, nor another from New Caledonia also 
Table 1 Changes to family and generic taxa of Thalassinidea since Poore (1994). Sakai's (1999a) synonymies are not followed here.

\section{Additional families and subfamilies}

Calliapaguropinae Sakai, 1999a in Callianassidae (type genus Calliapagurops de Saint Laurent, 1973).

Gourretiinae Sakai, 1999b in Callianassidae (type genus Gourretia de Saint Laurent, 1973), elevated to family rank by Sakai (2004b). Sakai (1999b) erected Gourretiinae for Gourettia and Dawsonius, placing Paracalliax in Ctenochelinae. Later, Sakai (2004b) elevated the subfamily to family rank adding Callianopsis, Laurentgourretia and Paragourretia and placing Paracalliax this time in Callianassidae. If this taxonomic arrangement is followed, Callianopsinae Manning and Felder, 1991 has precedence as a family level name. Manning and Felder (1991) and Tudge et al. (2000) suggested that Anacalliax is also a member of this group, making Anacalliacinae Manning and Felder, 1991 the senior family name over both Gourretiinae Sakai, 1999 and Callianopsinae Manning and Felder, 1991.

Eiconaxiidae Sakai and Ohta, 2005 (type genus Eiconaxius Bate, 1888), from Axiidae.

\section{Additional genera}

Axiidae

Manaxius Kensley, 2003 (type species Axiopsis (Axiopsis) pitatucensis de Man, 1925).

Marianaxius Kensley, 1996b (type species Marianaxius kroppi Kensley, 1996).

Paraxiopsis de Man, 1905 (type species Axius brocki de Man, 1888) reinstated by Kensley, 1996 a.

Platyaxius Sakai, 1994 (type species Platyaxius brevirostris Sakai, 1994).

\section{Callianassidae}

Bathycalliax Sakai and Türkay, 1999 (type species Bathycalliax geomar Sakai and Türkay, 1999).

Calliaxina Ngoc-Ho, 2003 (type species Calliax punica de Saint Laurent and Manning, 1982).

Grynaminna Poore, 2000 (type species Grynaminna tamakii Poore, 2000).

Lipkecallianassa Sakai, 2002 (type species Likpecallianassa abyssa Sakai, 2002).

Michaelcallianassa Sakai, 2002 (type species Michaelcallianassa indica Sakai, 2002).

Necallianassa Heard and Manning, 1998 (type species Necallianassa berylae Heard and Manning, 1998).

Nihonotrypaea Manning and Tamaki, 1998 (type species Callianassa japonica Ortmann, 1891).

Paraglypturus Türkay and Sakai, 1995 (type species Paraglypturus calderus Türkay and Sakai, 1995).
Pestarella Ngoc-Ho, 2003 (type species Astacus tyrrhenus Petagna, 1792).

Podocallichirus Sakai, 1999a (type species Callianassa madagassa Lenz and Richters, 1881).

Pseudobiffarius Heard and Manning, 2000 (type species Pseudobiffarius caesari Heard and Manning, 2000).

\section{Calocarididae}

Briancaris Sakai and Ohta, 2005 (type species Ambiaxius japonicus Kensley, 1976b).

Paracalocaris Sakai, 1991 (type species Paracalocaris sagamiensis Sakai, 1991)

Anacalliacinae (Ctenochelidae)

Paragourretia Sakai, 2004b (type species Gourretia phuketensis Sakai, 2002).

Laurentgourretia Sakai, 2004b (type species Laurentgourretia rhopalommata Sakai, 2004).

\section{Laomediidae}

Espeleonaushonia Juarrero and Martínez-Iglesias, 1997 (type species Espeleonaushonia augudrea Juarrero and García, 1997).

\section{Upogebiidae}

Aethogebia Williams, 1993 (type species Aethogebia gorei Williams, 1993).

Austinogebia Ngoc-Ho, 2001 (type species Upogebia narutensis Sakai, 1986)

\section{New synonymies proposed}

Corallichirus Manning, 1992 - synonymised with Corallianassa by Ngoc-Ho (2005)

Trypaea Dana, 1852, Cheramus Bate, 1888, Scallasis Bate, 1888, Biffarius Manning and Felder, 1991, Neotrypaea Manning and Felder, 1991, Notiax Manning and Felder, 1991, Poti Rodrigues and Manning, 1992 Gilvossius Manning and Felder, 1992, Necallianassa Heard and Manning, 1998, Nihonotrypaea Manning and Tamaki, 1998 - all synonymised with Callianassa Leach, 1814 by Sakai (1999a)

Corallianassa Manning, 1987, Corallichirus Manning, 1992 - synonymised with Glypturus Stimpson, 1866 by Sakai (1999a)

Sergio Manning and Lemaitre, 1994 - synonymised with Neocallichirus Sakai, 1988 by Sakai (1999a)

Eucalliax Manning and Felder, 1991 - synonymised with Calliax de Saint Laurent, 1973 by Sakai (1999a)

Pestarella Ngoc-Ho, 2003 - "difficult to accept" and synonymised with Callianassa Leach, 1814 by Sakai (2004a) referred to, are B. rudis. A north-western Australian record from off the Dampier Archipelago of $B$. rudis (Sakai, 1994) is of a specimen with three lateral rostral spines ( $B$. rudis has two) and may also belong to another species.

\section{Bouvieraxius michelae sp. nov.} Figure 1

\section{Material examined}

\section{Holotype}

Timor Sea. NMV J 47585, (male, cl $4.2 \mathrm{~mm}$, tl $10.8 \mathrm{~mm}$, without maxillipeds 3 or pereopods except right regenerating pereopod 1 and right pereopod 2; stained with chorazol black), stn SAHUL 136, Sahul Banks, unnamed shoal $\mathrm{W}$ of Mangol Shoal $\left(11^{\circ} 40.26^{\prime} \mathrm{S}, 125^{\circ} 04.84^{\prime} \mathrm{E}\right)$, top of 


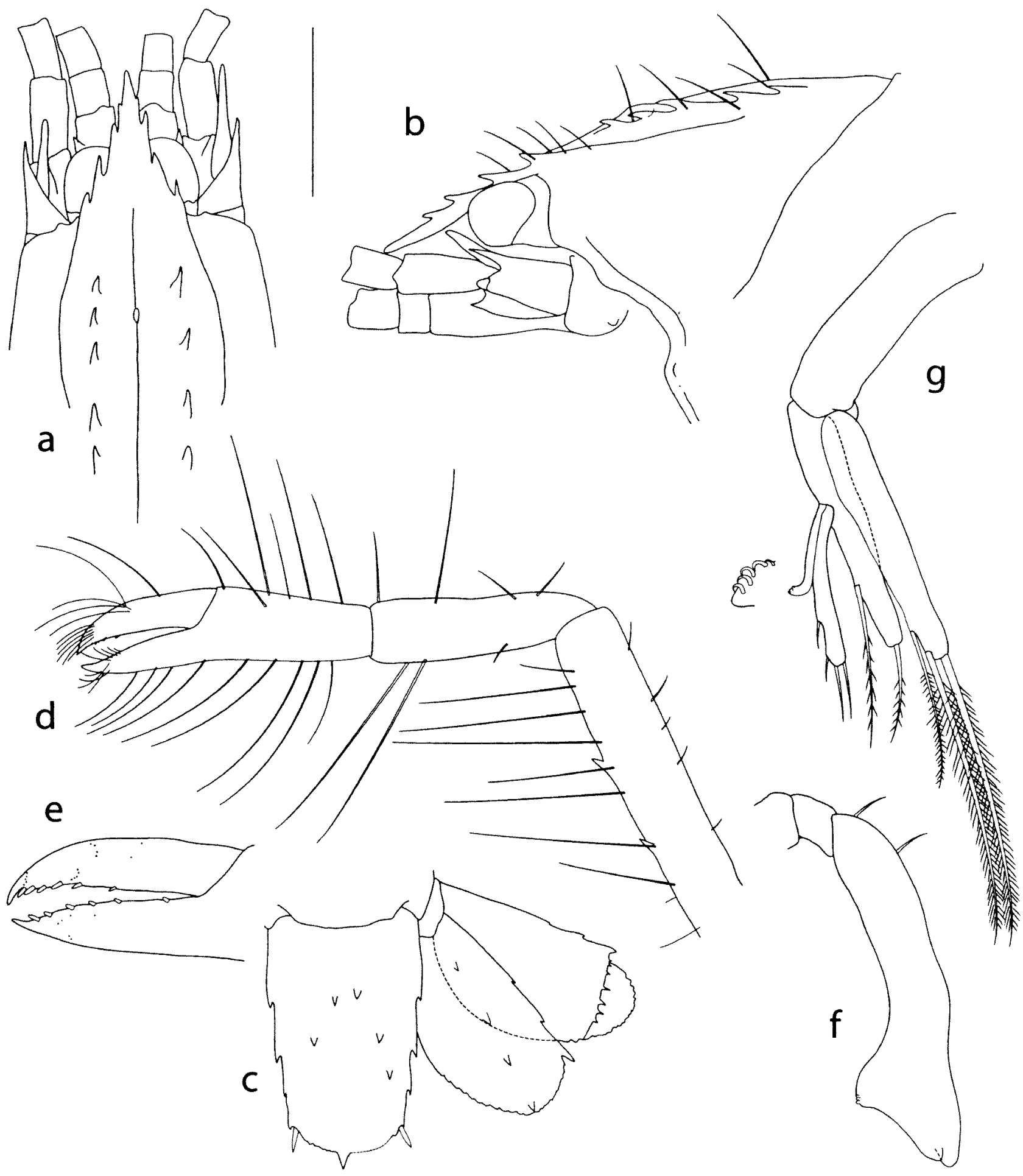

Figure 1 Bouvieraxius michelae sp. nov. Holotype male, NMV J 47585. a, b, dorsal and lateral views of carapace, eyes and bases of antennae; $c$, telson and right uropod; $d$, e, pereopod 2 and detail; $f$, pleopod $1 ; g$ pleopod 2 (with detail of coupling hooks on appendix interna). (scale bar $=1 \mathrm{~mm}, \mathbf{a}-\mathrm{c}$ only)

shoal, naturalists' dredge, $18 \mathrm{~m}$, coll. G.C.B. Poore et al. (with Consulting Enviromental Engineers), 26.10.2001.

\section{Diagnosis}

Rostrum with 4 spines on each side, last being supraorbital and at anterior end of lateral carina. Submedian row with 4 or 5 spines on obsolete ridge. Abdominal epimera 2-5 rounded, with minute hook near anterior end; epimeron 6 with hook at midpoint. Telson width at midpoint 0.58 greatest length, with 4 spines on each side, 2 or 3 spines on oblique ridges, apical margin semicircular, with median spine. Uropodal exopod without longitudinal row of spines; endopod greatest width half length. 


\section{Description of Holotype}

Carapace smooth, with 1 seta plus oblique row of 3 plumose setae anterolaterally; with dorsum depressing anteriorly on to rostrum. Rostrum narrowly triangular, depressed anteriorly, slightly asymmetrical; supraorbital spine at anterior end of lateral carina, just covering cornea, with 3 spines more distally; lateral carina smooth. Median carina visible as far posterior as cervical groove, without spines. Submedian row of 4 teeth on right, 5 on left. Anterolateral margin with broad antennal lobe, no tooth. Abdominal epimeron 1 triangular; epimera 2-5 rounded, with minute hook near anterior end; epimeron 6 with hook at midpoint. Telson width at midpoint 0.58 total length, with 4 lateral spines, first at about 0.4 length, last on posterolateral angle with 1 longer moveable spine; oblique asymmetrical dorsal ridges on posterior two-thirds with 2 spines on left and 3 on right side; apical margin semicircular, setose, with median spine.

Eyestalk 0.5 length of rostrum (measured from anterolateral margin); cornea pigmented light brown. Antenna 1 peduncle inflated, with minute distolateral tooth (stylocerite); articles 2 and 3 not much longer than wide, not reaching to end of antenna 2 peduncle ; flagella each with $\sim 30$ articles. Antenna 2 article 2 with distolateral projection; article 3 with distal tooth ventrally; scaphocerite simple, acute (asymmetrical, shorter on left); article 4 as long as 2 and 3 combined; article 5 half as long.

Pereopod 2 merus with 2 teeth on lower margin; fingers 0.45 length of propodus, with 6 small robust setae on cutting edges, concentrated distally.

Pleopod 1 a broad blade, dilated distally, with oblique apex ending in 2 lobes; with 3 minute coupling hooks. Pleopod 2 appendix interna about third of endopod length; appendix masculina about 0.60 length of endopod, with 2 mesial and 2 distal setae; endopod with 1 mesial and 1 distal setae; exopod longer than endopod, with 4 distal setae.

Uropodal endopod greatest width 0.5 length; lateral margin with 2 spines and strong distal spine; with oblique dorsal row of 4 spines. Exopod greatest width 0.5 length; without longitudinal row of spines, with 7 irregularly spaced spines on suture; lateral margin with 2 spines and distal spine; strong articulating spine lateral at end of suture; distomesial margin with numerous marginal setae plus supplementary stout and finer setae.

Branchial formula $(f=$ filamentous; $r=$ rudimentary):

$\begin{array}{lllllllll}\text { Thoracomere } & 1 & 2 & 3 & 4 & 5 & 6 & 7 & 8\end{array}$

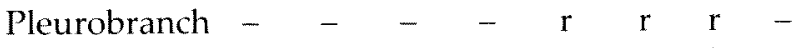
Arthrobranch - $\quad \begin{array}{llllllll}2 & 2 & 2 & 2 & 2 & 2 & -\end{array}$ $\begin{array}{llllllllll}\text { Epipod } \quad- & 1 & 1 & 1 & 1 & 1 & 1 & -\end{array}$ Podobranch - - f $f$ f $f$ -

\section{Remarks}

The holotype is the only specimen but possesses only one thoracic limb, a pereopod 2. Nevertheless, sufficient characters remain to be confident that Bouvieraxius michelae is a valid new species. It differs from $B$. rudis in dentition of the rostrum and submedial row, and in the narrower telson and uropods. The specimen from Madagascar (Sakai and de Saint Laurent, 1989: figs 13, 14) has a wider telson and uropods, and fewer submedian spines on a more definite ridge. Bouvieraxius springeri Kensley, 1996, from the Sulu Sea west of the Timor Sea and from Guam (Kensley, 2003), differs in having only one pair of lateral rostral spines, three well spaced submedian spines, and a broader telson with two pairs of spines on the oblique ridges; it is similar to the specimen from Madagascar illustrated as B. rudis by Sakai and de Saint Laurent (1989: figs 13, 14).

\section{Etymology}

The specific name honours Michèle de Saint Laurent (1926-2003) who inspired my studies of Thalassinidea.

\section{Paraxiopsis de Man, 1905}

Axius (Paraxiopsis) de Man, 1905: 597.

Paraxiopsis. - Sakai and de Saint Laurent, 1989: 3, 51. - Kensley, 1996a: 709-712 [key to Western Atlantic species]. - Ngoc-Ho et al., 2005: 200 201. - Kensley, 2003: 372.

Eutrichocheles. - Sakai and de Saint Laurent, 1989: 51. - Sakai, 1992a: 168. - Sakai, 1994: 185) (in part) (not Wood-Mason, 1876).

\section{Remarks}

Species of Paraxiopsis are diagnosed by a bifurcate antenna 2 scaphocerite and the pereopod 1 fixed finger (without basal strong tubercle) and dactylus closing or almost so. Also, the carapace is without a postcervical carina, uropodal exopod with a transverse suture, telson with a midposterior spine, pereopodal epipods present, pleurobranchs absent, rostrum broad and toothed, pleopods 2-5 without appendix interna, and male pleopod 1 absent or vestigial. Kensley (1996a) revived Paraxiopsis, synonymised by Sakai and de Saint Laurent (1989) with Eutrichocheles Wood-Mason, 1876. He stated that the male pleopod 1 is absent whereas it is vestigial in $P$. brocki (de Man, 1888), $P$. pumilus (Sakai, 1994) and the new species described here. Kensley (1996a) diagnosed Paraxiopsis as "gonochoristic (some species possibly hermaphroditic)." The holotype of the new species has gonopores on coxae of both pereopods 3 and 5 and has minute pleopods 1 . Pleopod 2 is without an appendix masculina.

The genus does not appear in Poore's (1994) key but differs from Eutrichocheles (which does) in the 
absence of postcervical median carina, absence of a gape and tubercle on the fixed finger of pereopod 1 , and smaller size. Ten species of Paraxiopsis are known from the Pacific and seven from the Atlantic (Kensley, 1996a, 2003). One of these, the nominal species $P$. brocki, occurs throughout the southwestern Pacific and Indian Ocean, including northern to western Australia but, as discussed below, this may comprise more than one species. Two others were described from northern Australia as species of Eutrichocheles, $P$. austrinus and $P$. pumilus (Sakai, 1994). The diagnosis of the new species is based on the characters in Kensley's (1996a, 2003) key and table.

\section{Paraxiopsis dianae sp. nov.}

Figure 2

\section{Material examined}

\section{Holotype}

Western Australia, Dampier Archipelago. WAM C 28060 (hermaphrodite, cl $7.1 \mathrm{~mm}, \mathrm{tl} 18.4 \mathrm{~mm}$; stained with chorazol black), stn DA3/99/40, Brigadier I. $\left(20^{\circ} 26.648^{\prime} \mathrm{S}, 116^{\circ} 36.522^{\prime} \mathrm{E}\right), 6.0-14.0 \mathrm{~m}$, limestone reef dissected by deep gullies with sandy floors, many soft and hard corals, coll. M. Hewitt et al., 28.08.1999.

\section{Other material}

Western Australia, Dampier Archipelago. WAM C 29564 (juvenile, cl. $4.1 \mathrm{~mm}$ ), stn DA2/99/92, approx. $3.9 \mathrm{n} . \mathrm{mi} .[7.2 \mathrm{~km}]$ NE of Bluff Point, Enderby I. $\left(20^{\circ} 34.64^{\prime} \mathrm{S}, 116^{\circ} 35.74^{\prime} \mathrm{E}\right), 17.0 \mathrm{~m}$, shelly mud, coll. M. Hewitt et al., 27.07.1999.

\section{Etymology}

The specific name honours Diana Jones, curator of Crustacea at the Western Australian Museum, who arranged the Western Australian MuseumWoodside Energy Partnership which facilitated sampling at the Dampier Archipelago.

\section{Diagnosis}

Carapace smooth. Rostrum-lateral carina with 2 spines on each side, supraorbital over-reaching cornea. Submedian carina curved, without teeth. Abdominal epimera 2-5 rounded, with minute hook near anterior end of 3-5. Telson with 2 spines on each side, apical margin semicircular. Maxilliped 3 crista dentata with 8 teeth; merus with 9 mesial spines. Pereopod 1 merus without spines on upper margin; chela fusiform, smooth, not setose, without distal tooth on upper margin. Uropodal exopod without longitudinal row of spines.

\section{Description of holotype}

Carapace smooth, with 1 seta plus oblique row of
3 plumose setae anterolaterally; with dorsum domed and defined anteriorly by curved pregastric groove. Rostrum narrowly triangular, depressed anteriorly but slightly upturned apically, hollow dorsally; supraorbital spine over-reaching cornea, with 1 small spine more distally on right side only, without spines between supraorbital and spine at anterior end of lateral carina; lateral carina smooth. Median carina weak, visible only anterior to submedian carinae, without spines. Submedian carina curved, without teeth. Anterolateral margin with broad antennal lobe, no tooth. Abdominal epimeron 1 triangular; epimera $2-5$ broadly rounded, with minute hook near anterior end of $3-$ 5. Telson width at midpoint 0.85 total length, lateral convexity at anterior quarter with minute spine; without spines between this and posterolateral fixed and moveable spines; oblique asymmetrical dorsal ridges on posterior half with 3 or 4 spines plus 1 more lateral on each side; apical margin semicircular, setose, with supplementary rows of finer setae and stouter short submarginal setae (median spine damaged).

Eyestalk 0.40 length of rostrum (measured from base of lateral rostral spine); cornea pigmented. Antenna 1 peduncle inflated, with minute distolateral tooth (stylocerite); articles 2 and 3 shorter, unarmed; flagella each with $\sim 30$ articles. Antenna 2 article 3 with single mesioventral tooth scaphocerite bifid, mesial tooth set halfway along margin; flagellum with 62 articles.

Maxilliped 3 ischium having crista dentata with 8 teeth; merus with 5 short irregular proximal and 4 longer distal spines on lower margin; carpus unarmed; exopod with 2 long proximal articles, 9 short distal articles, 1.25 times as long as merusischium.

Pereopods 1 equal, all articles with sharp crests on upper and lower margins; ischium with 2 spines on lower margin; merus with 2 proximal and 2 distal spines on lower margin, without spines on upper margin; carpus unarmed; chela fusiform in lateral view, greatest depth 0.70 length of upper margin, smooth, not setose, without distal tooth on upper margin; fixed finger 0.45 total length of propodus, with slight blade proximally and obscure teeth distally on cutting edge; dactylus strongly curved. Pereopod 2 ischium unarmed; merus with 1 minute proximal spine on lower margin; fingers with short robust setae along cutting edges, 28 on fixed finger, 22 on dactylus. Pereopod 3 propodus with 10 robust setae on lower margin plus 1 larger distally at base of dactylus; dactylus with 7 robust setae. Pereopod 4 propodus with 2 rows of robust setae, 7 in upper and 11 in lower (some paired), 1 much larger distal seta adjacent to row of 6 shorter setae; lower margin with 10 complex oblique setae distally; dactylus with 11 robust robust setae Pereopod 5 with triangular fixed finger, quarter 


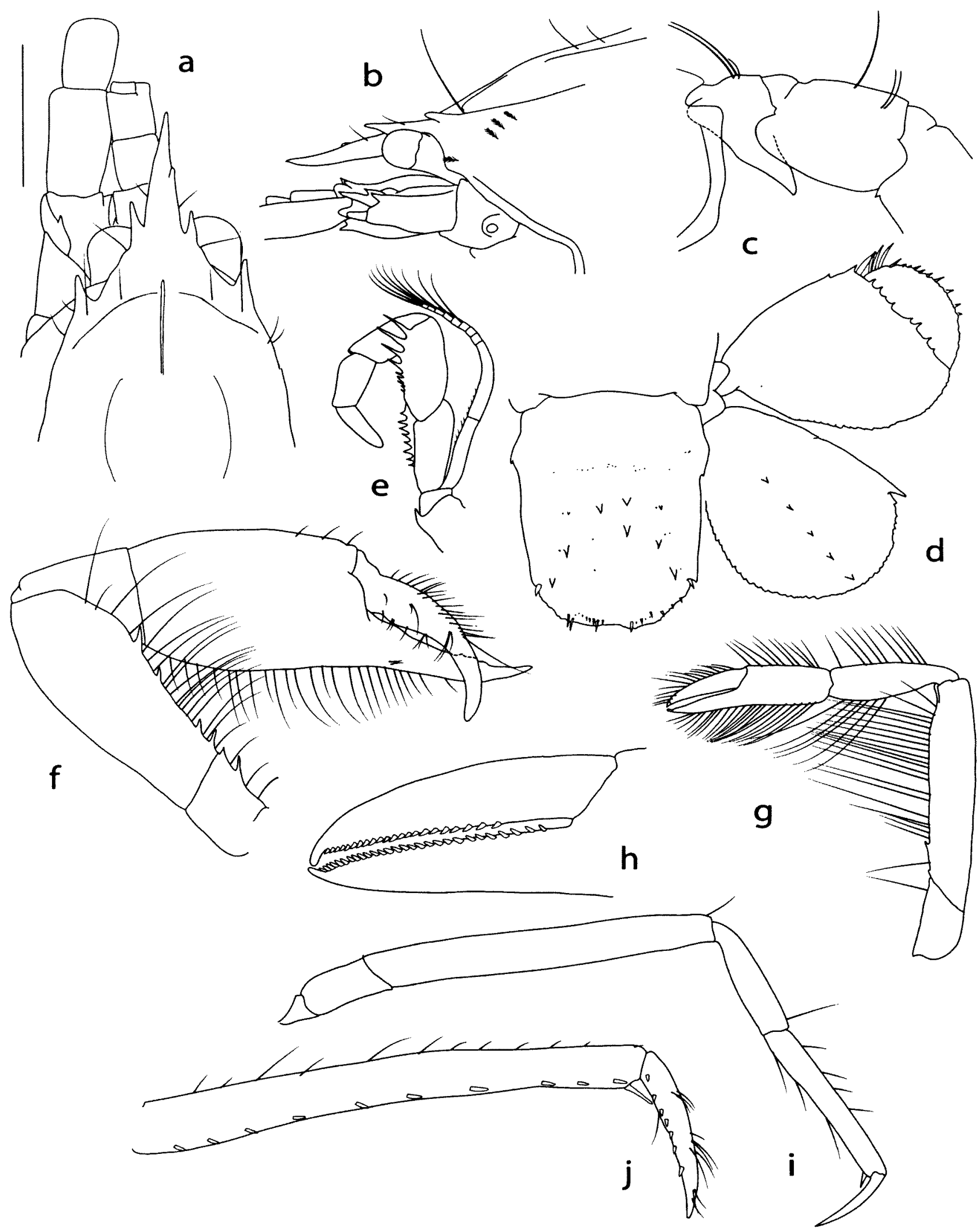

Figure 2 Paraxiopsis dianae sp. nov. Holotype hermaphrodite, WAM C 28060. a, b, dorsal and lateral views of carapace, eyes and bases of antennae; c, telson and right uropod; d, maxilliped 3; e, pereopod $1 ; \mathbf{f}, \mathbf{g}$, pereopod 2 and detail; $h$, i, pereopod 3 and detail. (scale bar $=2 \mathrm{~mm}$, a-d only) 


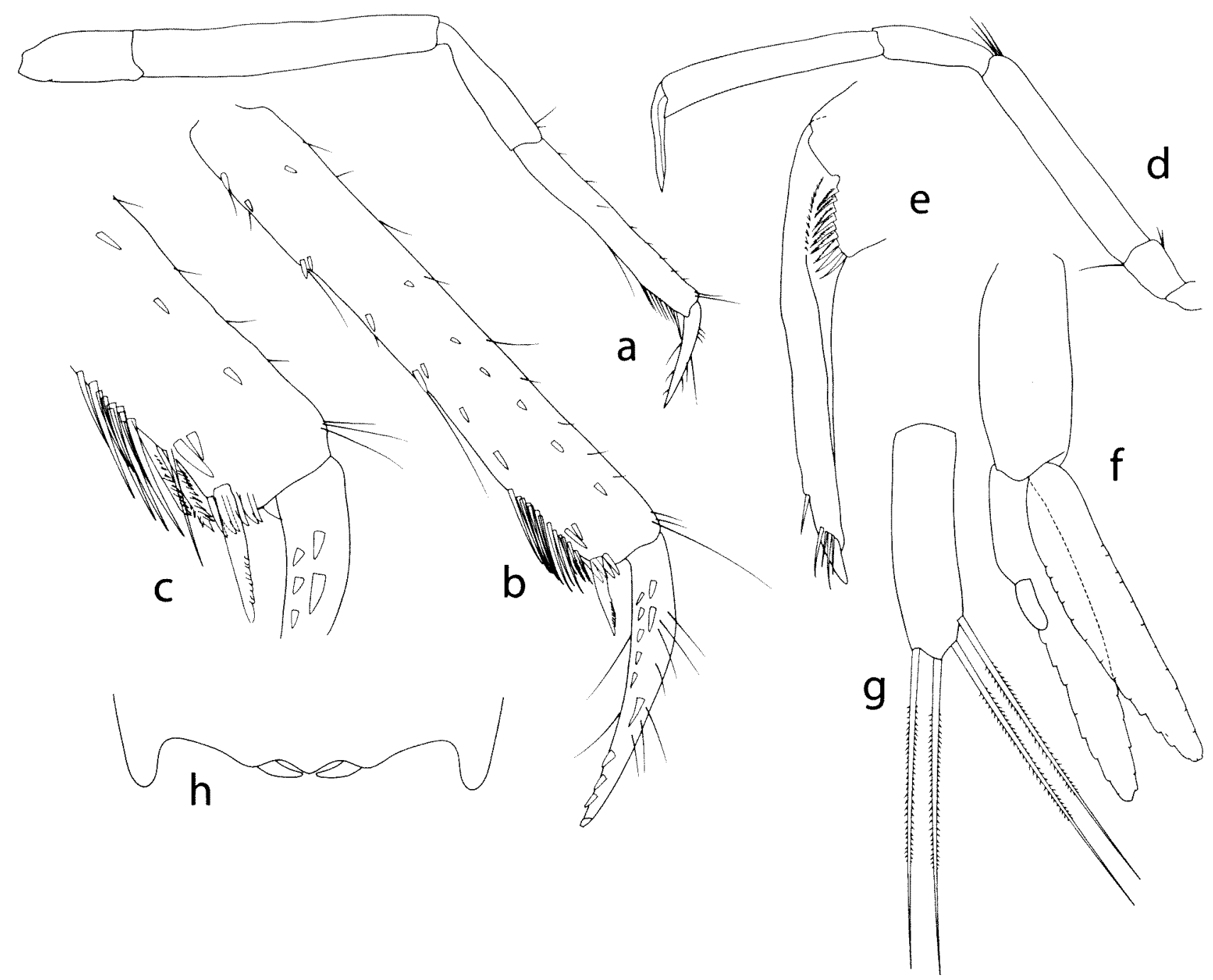

Figure 3 Paraxiopsis dianae sp. nov. Holotype hermaphrodite, WAM C 28060. a, b, c, pereopod 4 and detail; d, e, pereopod 5 and detail; $\mathbf{f}, \mathbf{g}$, pleopod 2 detail of appendix interna; $\mathbf{h}$, ventral posterior margin of abdominal somite 1 showing pleopods 1 .

length of flattened dactylus, armed with $\sim 9$ pectinate setae.

Gonopores on coxae of pereopods 3 and 5 .

Pleopod 1 minute, tapering, digitiform, mesially directed along posterior margin of sternite of abdominal somite 1. Pleopod 2 appendix interna 0.15 length of endopod, with 4 apical setae.

Uropodal endopod greatest width 0.75 length; lateral margin with minute mid-tooth and strong distal tooth; distomesial margin with $\sim 50$ marginal setae plus supplementary stout and finer setae; with oblique dorsal row of 5 spines. Exopod greatest width 0.80 length; without longitudinal row of spines, with 8 irregularly spaced spines on suture; lateral margin with distal and subdistal spines; strong articulating spine lateral at end of suture; distomesial margin with numerous marginal setae plus supplementary stout and finer setae.
Branchial formula (f=filamentous; $r=$ rudimentary): Thoracomere $\begin{array}{lllllllll}1 & 2 & 3 & 4 & 5 & 6 & 7 & 8\end{array}$ Arthrobranch - $\begin{array}{llllllll} & \mathrm{r} & 2 & 2 & 2 & 2 & 2 & -\end{array}$ $\begin{array}{lllllllll}\text { Epipod } & 1 & 1 & 1 & 1 & 1 & 1 & 1 & -\end{array}$ Podobranch - $-f$ f f f - -

\section{Remarks}

The new species most resembles $P$. brocki whose wide geographic range includes the Dampier Archipelago. Paraxiopsis brocki has been illustrated (as member of Axius, Axiopsis, Paraxiopsis or Eutrichocheles), seven times (see citations in Kensley, 1996a; Ngoc-Ho, 1998). Figures of de Man (1888; 1925), Tirmizi (1983), Kensley (1996a) and Ngoc-Ho (1998) are of individuals with prominent supraocular spines at the base of the rostrum, with or without minute lateral spines on the rostrum, with or without 
another prominent spine behind the supraocular, a straight submedian ridge, continuous or divided into two, and an almost-truncate or rounded telson. The individual from Garden Island, WA, illustrated by Poore and Griffin (1979) has strong lateral spines on the rostrum, a less rounded telson with fewer lateral spines than those of de Man (1888) or Kensley (1996a). It has much finer teeth on the crista dentata of maxilliped 3 than illustrated by Kensley (1996a). This individual may belong to another species; Poore and Griffin (1979) also mentioned another specimen from this southern region that differed in other ways. Both sexes and similar-sized animals (tl 17-19 $\mathrm{mm}$ ) have been reported in the material already described and it is possible that more than one species is represented (differences summarised in Table 2). Ngoc-Ho (1998) also compared several accounts of this species with her own from Tuamotu but did not conclude that more than one species was involved.

The new species differs from all so-called $P$. brock $i$ in having the 'supraocular' rostral spine well advanced of the eye compared to all others, and a more compact and smooth palm of pereopod 1 . Table 2 illustrates other differences from published accounts but comparisons with actual specimens have not been made for this study. The new species has fewer spines and robust setae on pereopods than $P$. brocki. The pattern of setae on the propodus of pereopod 4 is quite different with robust setae concentrated distally (cf. Tirmizi, 1983; Kensley, 1996a). Mouthparts of the new species were dissected but did not differ obviously from those of P. brocki illustrated by Poore and Griffin (1979) or Kensley (1996).

The second specimen, a small juvenile, lacks pleopod 1 and appendix interna on pleopod 2 .

\section{Spongiaxius Sakai and de Saint Laurent, 1989}

Spongiaxius Sakai and de Saint Laurent, 1989: 41.

\section{Remarks}

Species of Spongiaxius, four known, inhabit sponges. Here, the type species is reported for the third time.

\section{Spongiaxius brucei (Sakai, 1986)}

Axiopsis brucei Sakai, 1986: 11, figs 1-6.

Spongiaxius brucei. - Sakai and de Saint Laurent, 1989: 44-45, fig. 3F. - Sakai and Ohta, 2005: 8990, fig. 11.

\section{Material examined}

Western Australia. WAM C 35565 (1 male, cl. 24 $\mathrm{mm}$ ); NMV J 53339 (female, cl. $19 \mathrm{~mm}$ ), W of
Lacepede Archipelago (16 $6^{\circ} 56.7^{\prime} \mathrm{S}, 119^{\circ} 51.1^{\prime} \mathrm{E}$ to $\left.16^{\circ} 52.7^{\prime} \mathrm{S}, 119^{\circ} 53.8^{\prime} \mathrm{E}\right), 434-433 \mathrm{~m}$, soft bottom, coll. S. Slack-Smith on F.R.V. Soela, 22.02.1984; WAM C 35566 (female, cl. $26 \mathrm{~mm}$ ), WNW of Lacepede Archipelago $\left(15^{\circ} 46.4^{\prime} \mathrm{S}, 120^{\circ} 39.9^{\prime} \mathrm{E}\right.$ to $15^{\circ} 43.8^{\prime} \mathrm{S}$, $\left.120^{\circ} 39.8^{\prime} \mathrm{E}\right)$, unknown depth, coll. S. Slack-Smith on F.R.V. Soela, 10.02.1984.

\section{Remarks}

New material of this large, distinctive species comes not far from and at a depth very similar to those of the types. Sakai and Ohta's (2005) material comes from the Sulu Sea at $690 \mathrm{~m}$ depth. The depressed rostrum has a marginal row of up to 20 erect spines and is clearly separated from five longitudinal rows of spines on the dorsal carapace. The types are from a hexactinellid sponge; no host was recorded for the new material.

\section{Family Callianassidae Dana, 1852}

\section{Remarks}

Poore (1994) provided a key to 20 genera but since then 11 nominal genera have been added (Table 1). There remains disagreement over the generic arrangement of Callianassidae. Tudge et al. (2000) suggested more genera might be justified on the basis of a phylogenetic analysis but Sakai (1999b) synonymised several with Callianassa while erecting others. The two new species are placed in a genus with provisos.

\section{Biffarius Manning and Felder, 1991}

Biffarius Manning and Felder, 1991: 769-770. Poore, 1994: 102 [key].

\section{Diagnosis}

Rostrum flattened, broadly triangular. Eyestalks with flattened lobe beyond cornea. Maxilliped 3 merus barely or not projecting beyond articulation with carpus. Pereopods 1 unequal. Uropodal endopod subquadrate, broadened distally. Appendices internae on pleopods 3-5 short but clearly emerging from margin of endopod. Antenna 1 peduncle shorter than antenna 2 peduncle; or antennae 1 and 2 peduncles of similar lengths and widths. Maxilliped 3 subpediform, ischium-merus about twice merus width. Telson tapering to posterior truncate (or concave) margin. Pleopod 2 of male absent.

\section{Remarks}

This is one of several genera synonymised with Callianassa Leach, 1814 by Sakai (1999a). It comprises central American and Australian species united by a unique suite of characters and is supported in the phylogeny of Tudge et al. (2000). 
Table 2 Comparison of Paraxiopsis dianae with six published descriptions of Paraxiopsis brocki. De Man (1888) and de Man (1925) are based in part on the same material but illustrations do differ.

\begin{tabular}{|c|c|c|c|c|c|c|c|}
\hline Character & dianae & de Man, 1888 & de Man, 1925 & Poore and Griffin, 1979 & Tirmizi, 1983 & Kensley, 1996a & Ngoc-Ho, 1998 \\
\hline Locality & Dampier Archipelago & Bomeo (type) & Amboina, Indonesia & Garden I., WA & Ambon, Indonesia & Bikini Atoll & Tuamotu \\
\hline $\begin{array}{l}\text { Rostral-lateral } \\
\text { carina spines }\end{array}$ & 2 & 3 & 2,3 & 4 & 2,3 & 2 & 3 \\
\hline Supraorbital spine & reaching over comea & \multicolumn{6}{|c|}{ at base of eyestalk } \\
\hline Submedian carina & curved, continuous & straight, oblique & straight, bipartite & straight & straight & straight, bipartite & $\begin{array}{l}\text { slightly curved, } \\
\text { with anterior spine }\end{array}$ \\
\hline $\begin{array}{l}\text { Maxilliped } 3 \text { crista } \\
\text { dentata teeth }\end{array}$ & 8 & $?$ & 14 & -20 & $\sim 14$ & $7-9$ & 14 \\
\hline $\begin{array}{l}\text { Maxilliped } 3 \text { merus } \\
\text { short + long spines }\end{array}$ & $5+4$ & $?$ & 6 & $0+2$ & $2+2$ & $5-7+2$ & $2+2$ \\
\hline Pereopod 1 chela & fusiliform, smooth & \multicolumn{2}{|c|}{ fusiliform, smooth, upper margin ridged } & $\begin{array}{l}\text { cylindrical, denticulate } \\
\text { surface }\end{array}$ & $\begin{array}{l}\text { cylindrical, upper } \\
\text { margin crenulate, } \\
\text { denticulate surface }\end{array}$ & $\begin{array}{l}\text { cylindrical, upper } \\
\text { margin crenulate }\end{array}$ & $\begin{array}{l}\text { cylindrical, } \\
\text { smooth }\end{array}$ \\
\hline Pereopod 1 fingers & $\begin{array}{l}0,70 \text { palm, evenly } \\
\text { curved, minutely } \\
\text { denticulate }\end{array}$ & \multicolumn{2}{|c|}{$\begin{array}{l}0.70 \text { palm, evenly curved, } \\
\text { minutely denticulate }\end{array}$} & $\begin{array}{l}0.70 \text { palm, distally } \\
\text { curved, with strong } \\
\text { basal tooth, dentate }\end{array}$ & $\begin{array}{l}0.79 \text { palm, distally } \\
\text { curved, with strong } \\
\text { basal tooth, dentate }\end{array}$ & $\begin{array}{c}0.55 \text { palm, with strong } \\
\text { basal tooth, dentate } \\
\text { basal blade }\end{array}$ & $\begin{array}{l}0.55 \text { palm, with } \\
\text { prominent } \\
\text { dentate }\end{array}$ \\
\hline $\begin{array}{l}\text { Telson, width at } \\
\text { midpoint/length }\end{array}$ & 0.85 & 0.95 & 0.70 & 0.75 & 0.93 & 0.85 & 0.80 \\
\hline Telson, lateral spines & 2 & 5 & 3 & 1 & 4 & 4 & 4 \\
\hline $\begin{array}{l}\text { Telson, posterior } \\
\text { margin }\end{array}$ & semicircular & curved/truncate & semicircular & truncate-semicircular & truncate-semicircular & semicircular & $\begin{array}{l}\text { truncate- } \\
\text { semicircular }\end{array}$ \\
\hline Male pleopod 1 & small & $?$ & "rudimentary" & small & $?$ & absent & $?$ \\
\hline
\end{tabular}


Biffarius melissae sp. nov.

Figure 4

\section{Material examined}

\section{Holotype}

Western Australia, Dampier Archipelago. C 29565 (female, cl $3.8 \mathrm{~mm}$, tl $15.6 \mathrm{~mm}$ ), stn DA2/99/ 03 Mermaid Sound, approx $2 \mathrm{n}$. mi. [3.6 km] NW of Cohen I. (20'22.14'S, $\left.116^{\circ} 46.13^{\prime} \mathrm{E}\right), 32-35 \mathrm{~m}$, muddy sand, coralline red algae and Halophila, coll. M. Hewitt et al., 14.07.1999.

\section{Paratype}

Western Australia, Dampier Archipelago. WAM C 29566 (1 male, cl. $3.8 \mathrm{~mm}$, without chelipeds), from type locality.

\section{Diagnosis}

Rostrum triangular. Telson subquadrate, 1.05 times as wide as long. Eyestalks with broadlytriangular apical lobes; cornea pigmented and domed. Antenna 1 peduncle slightly longer than antenna 2 peduncle. Maxilliped 3 operculiform, ischium-merus 2.0 times as long as greatest width, with 18 teeth in crista dentata; carpus, propodus and dactylus all narrow. Pereopods 1 (female) unequal, dissimilar; larger cheliped ishium finely denticulate on lower margin, merus with denticulate, distally-directed tooth on lower margin, carpus, propodus and dactylus unarmed; smaller cheliped merus with small tooth on lower margin. Uropod endopod oval, with straight outer margin; exopod almost semicircular, with rounded distal and inner margins, barely-concave outer margin.

\section{Description}

Notes additional to diagnosis from female holotype

Rostrum broadly triangular, reaching to half length of eyestalks. Carapace with linea thalassinica and dorsal oval well defined. Abdominal somites 3-5 with tufts of setae confined to small areas laterally. Telson with lateral margins almost parallel, slightly convex, tapering distally to more sharply rounded corners; distal margin convex.

Eyestalks with flat apical lobe, obliquely truncate; cornea subdistal, domed. Antenna 1 peduncle with article 3 twice as long as article 2, slightly overreaching antenna 2 . Antenna 2 with minute scaphocerite, article 50.8 length of article 4 . Maxilliped 3 without exopod; ischium-merus margins evenly curved, unarmed; propodus shorter than carpus; dactylus shorter than propodus, tapering.

Larger cheliped merus with denticulate, bladelike tooth along proximal half of lower margin; width : dorsal length ratios of merus, carpus, palm
$-0.60,0.66,0.91$; fingers simple, shorter than palm. Smaller cheliped with carpus width 0.35 length; fingers simple. Pereopod 2 width : dorsal length ratios of merus, carpus, propodus $-0.34,0.50,1.54$. Pereopod 3 propodus without proximal heel, lower margin evenly convex, depth 0.70 greatest dimension.

Female pleopod 1 with curved article 1, article 2 one-third as long as first, article 3 tapering, shorter than second. Female pleopod 2 with curved basis; exopod article 1 little shorter than basis, article 2 cylindrical, shorter than first; endopod as long as exopod. Pleopods $3-5$ with appendix interna longer than basal width. Uropodal endopod reaching further than telson, greatest width 0.6 times greatest length, inner margin evenly curved, upper surface with 5 strong setae near distal margin and 2 more proximally; exopod larger than endopod, greatest width 0.82 length.

\section{Additional notes from male}

Pleopod 1 curved, article 2 longer than first.

\section{Etymology}

The specific name honours Melissa Hewitt, Western Australian Museum, who organised much of the field work around the Dampier Archipelago for the Western Australian Museum-Woodside Petroleum Partnership.

\section{Remarks}

The male is without chelipeds. The new species keys to the genus Biffarius in Poore (1994) and by following the hierarchy of characters in Tudge et al. (2000). The species keys to the abundant southern Australian species, Callianassa arenosa Poore, 1975 in Sakai (1988; 1999a) although some of the character choices could be ambiguous. Biffarius was treated as a junior synonym of Callianassa in both Sakai's papers. The new species and arenosa have all of the diagnostic characters used by Manning and Felder (1991) and followed by Poore (1994) to define Biffarius. Biffarius melissae was compared with specimens of $B$. arenosus; the two share many similarities in addition to those diagnostic of the genus but are different. Both have short dorsal setae on the uropodal endopod, never before recorded. Differences in proportions can be seen in the shapes of the larger cheliped, maxilliped 3, uropod and telson.

A second tropical Australian species is Callianassa lewtonae Ngoc-Ho, 1994, placed in Biffarius by Tudge et al. (2000). This species is known only from females with similar-sized chelipeds, pleopods 1 and 2 similar to those of Biffarius (not reported by Ngoc-Ho but confirmed from types) and an elongate appendix interna on pleopods $3-5$. The chelipeds and appendix interna 


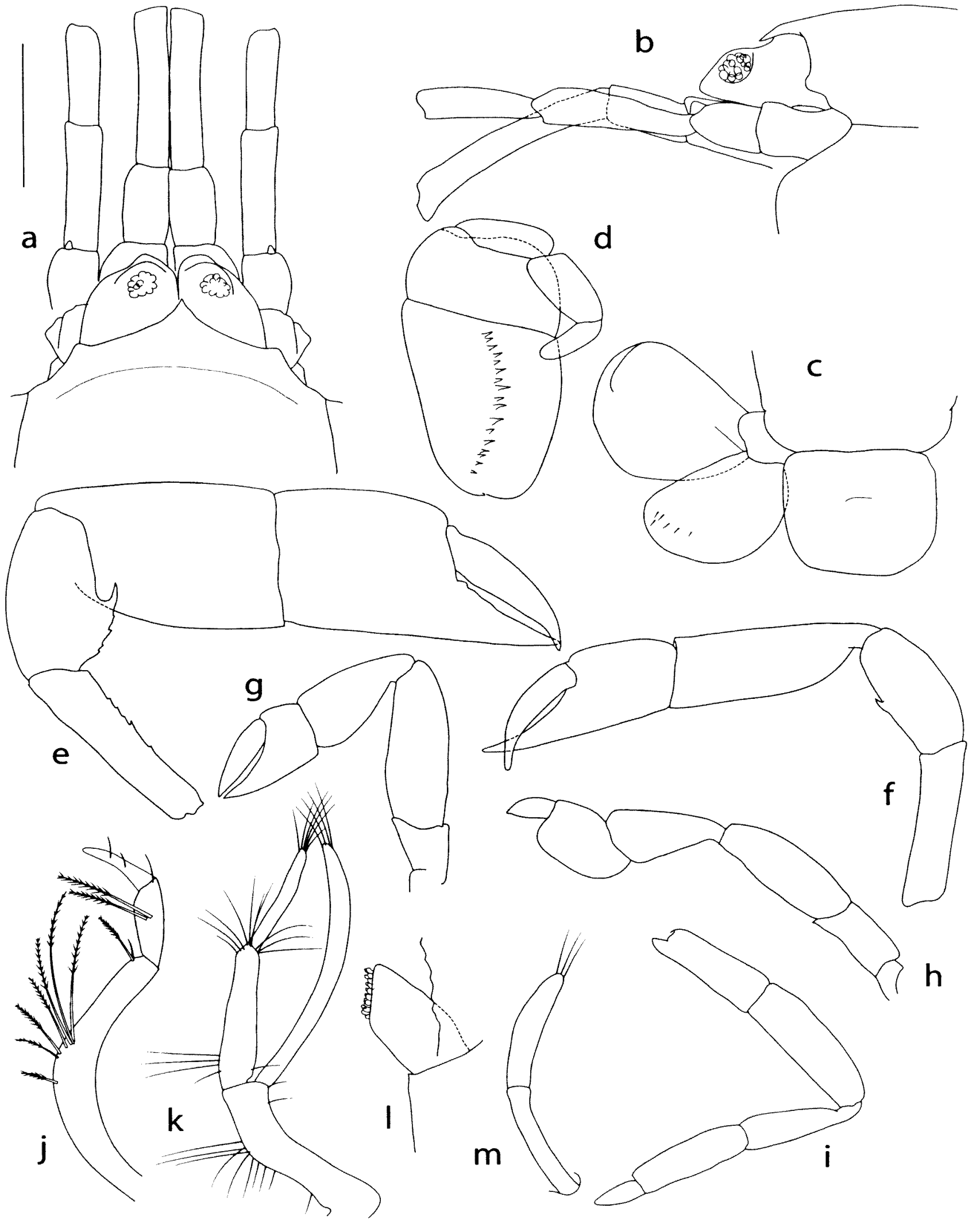

Figure 4 Biffarius melissae sp. nov. Holotype female, WAM C 29565. a, b. dorsal and lateral views of carapace, eyes and bases of antennae; $\mathbf{c}$, telson and left uropod; $\mathbf{d}$, maxilliped 3 ; e, left (major) pereopod 1 ; $\mathbf{f}$, right (minor) cheliped; g, pereopod $2 ; \mathbf{h}$, pereopod $3 ; \mathbf{i}$, pereopod $4 ; \mathbf{j}$, pleopod $1 ; \mathbf{k}$, pleopod $2 ; \mathbf{l}$, appendix interna of pleopod 3. Paratype male, WAM C 29566. m, pleopod 1. No setae shown on most figures. (scale bar $=1 \mathrm{~mm}$, $\mathrm{a}, \mathrm{b}$ only) 
exclude the species from Biffarius; its telson is more tapering than in the new species.

\section{Callianassa Leach, 1814}

Callianassa Leach, 1814: 385.

\section{Remarks}

Manning and Felder's (1991) concept of Callianassa Leach, 1814 is restricted to the type species and few others; they were largely supported by Tudge et al.'s (2000) phylogeny and by Ngoc-Ho (2003) who all reiterated problems with various views of the generic concepts in the family. Sakai (1999a) took a contrary view and redefined the genus to encompass a diversity of callianassid morphologies. Rather than erect a new genus simply on the basis of a new combination of supposed diagnostic characters I adopt a broad view of Callianassa.

\section{Callianassa amboinensis de Man, 1888}

Callianassa amboinensis de Man, 1888: 480, pl. 20 fig. 4. - Poore and Griffin, 1979: 248, fig. 14. Sakai, 1984: 96, figs 1, 2. - Sakai, 1988: 53, 57, fig. 14. - Ngoc-Ho, 1991: 283-284, fig. 1. Ngoc-Ho, 2005: 68-71, fig. 12 (complete synonymy).

Callianassa (Trypaea) amboinensis. - de Man, 1928: 165-170, pl. 18 fig. 28-28c.

Callianassa ngochoae Sakai, 1999a: 49.

\section{Material examined}

Western Australia, Dampier Archipelago. WAM C 29567 (2 females, 18 and $40 \mathrm{~mm}$ ), stn DA2/99/84, approx. $2.9 \mathrm{n}$. mls [5.4 km] E of Tish Pt, Rosemary I. $\left(20^{\circ} 29.94^{\prime} \mathrm{S}, 116^{\circ} 38.11^{\prime} \mathrm{E}\right), 12.5-15.0 \mathrm{~m}$, hard bottom, coll. M. Hewitt et al., 26.07.1999; WAM C 29568 (2 females, 21 and $24 \mathrm{~mm}$ ), stn DA2/99/99, $1.05 \mathrm{n}$. mls $[1.95 \mathrm{~km}]$ WSW of Rocky Head, Enderby $\mathrm{I}$. (2037.36'S, $\left.116^{\circ} 26.85^{\prime} \mathrm{E}\right), 17.0-19.0 \mathrm{~m}$, many sponges, corals, gorgonians, coll. M. Hewitt et al., 28.07 .1999 .

\section{Remarks}

Specimens attributed to this name have been illustrated at least seven times and Ngoc-Ho (2005) argued that all belong to the same species, a conclusion disputed by Sakai (1999a). Callianassa amboinensis occurs throughout northern Australia, the Great Barrier Reef, Indonesia, west to the Marquesas Islands, and also in Israel.The new collections are at the southern limit of the species' range in Western Australia. In the form of the telson (as long as wide but rounded corner between lateral and posterior margins), merus of larger pereopod 1 (lower margin convex and with minute proximal denticles), and pereopod 1 fixed finger (blade almost straight), these specimens are identical to those, also from the Dampier Archipelago, illustrated in detail by Poore and Griffin (1979). De Man's (1888) illustration of the $25 \mathrm{~mm}$-long type from Ambon shows a convex pereopod 1 merus (but without obvious denticles) and a fixed finger with two blunt steps. Its telson is more rectangular than the Dampier material. De Man's (1928) illustration of another Indonesian female shows a more tapering telson. Sakai's (1988) illustrations of a $21 \mathrm{~mm}$-long female from Darwin are essentially similar to De Man's. Sakai (1984) illustrated and discussed differences between two females of 31 and $44 \mathrm{~mm}$ from Heron Island, Queensland, in the prominence of the rostrum, curvature of the pereopod 1 merus lower margin and dentition of the fixed finger.

The male of $11.5 \mathrm{~mm}$ from New Caledonia (NgocHo, 1991) has more elongate pereopods 1 than females illustrated earlier. Sakai (1999a) erected a new species for it on the basis of different proportions of antennal 1 peduncles, serrations on pereopod 1 merus (but as in Poore and Griffin's and Sakai's [1988] figures) and longer telson (not true according to my measurements). Ngoc-Ho (2005) argued for her original identification and synonymised the two species. A $12-\mathrm{mm}$ long specimen from the Marquesas illustrated by her (2005) differs from the others in having a concave lower margin on the merus of both pereopods 1 and a blunt tooth on the fixed fingers.

While in total only one $11.5-\mathrm{mm}$ male and ten females (ovigerous from 11 to $44 \mathrm{~mm}$ ) are known, some uncertainty remains over whether this widespread species is one or more species.

Tudge et al. (2000) believed on the basis of a phylogenetic analysis that the species may deserve a separate genus but on their cladogram it is not far removed from Callianassa subterranea, type species of Callianassa. The species keys to Callianassa in my interactive key, sharing with this genus all except two of the characters used by Ngoc-Ho (2003) in her provisional diagnosis. One notable difference is absence of a meral hook on the major pereopod 1, present in the type species, but noted as variable in what Ngoc-Ho (2003) considered a polyphyletic genus. The second is that antenna 2 peduncle is shorter than the peduncle of antenna 1 in C. amboinensis but longer or as long in the type and other European species.

\section{Callianassa sahul sp. nov.} Figure 5

\section{Material examined}

\section{Holotype}

Timor Sea. NMV J 53340 (ovig. female, cl $4.3 \mathrm{~mm}$, 


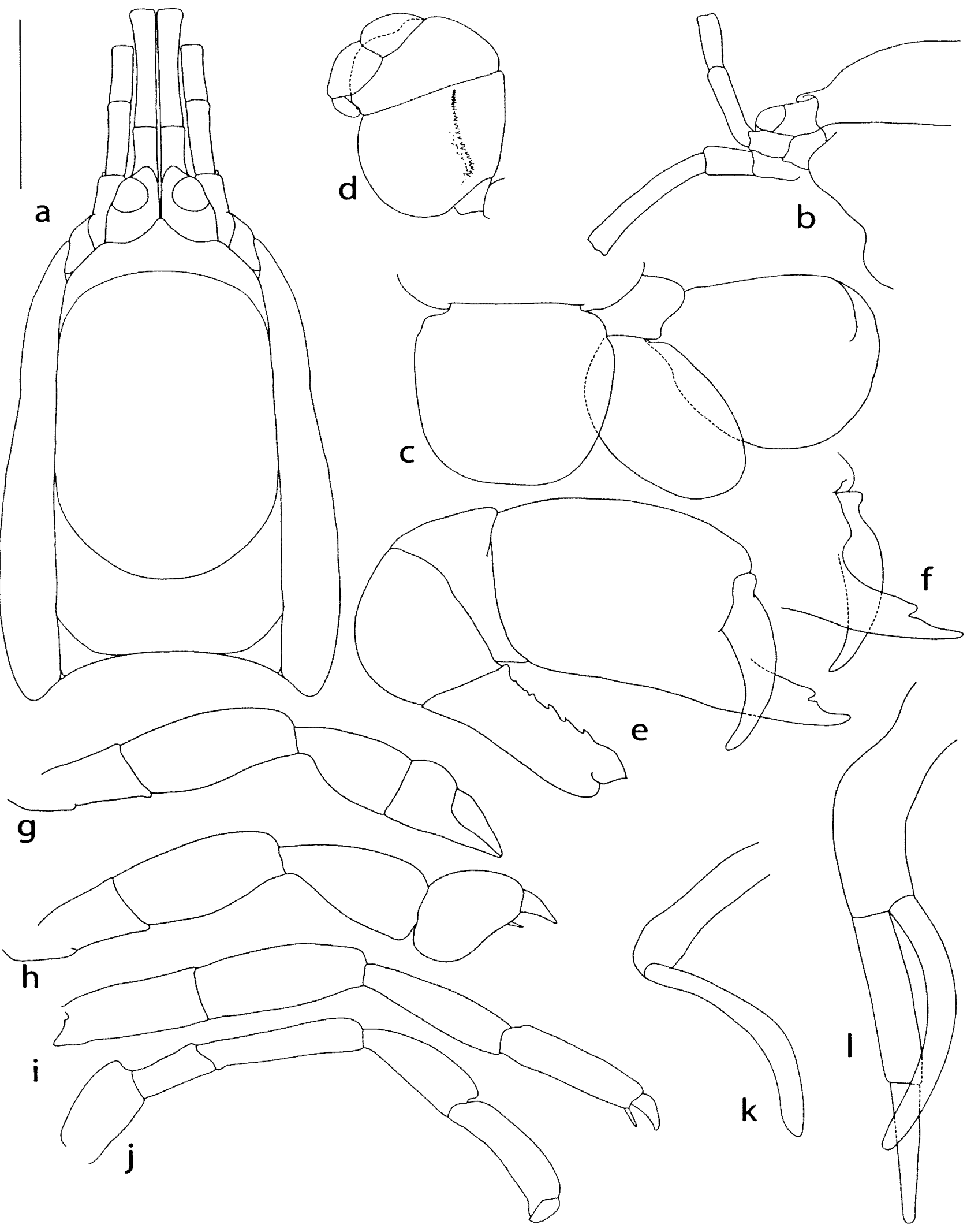

Figure 5 Callianassa sahul sp. nov. Holotype female, NMV J 53340. a, b, dorsal and lateral views of carapace, eyes and bases of antennae; $\mathrm{c}$, telson and right uropod; $\mathrm{d}$, maxilliped $3 ; \mathrm{e}, \mathrm{f}$, left cheliped and detail of fingers from lateral view; $\mathbf{g}$, pereopod $2 ; \mathbf{h}$, pereopod $3 ; \mathbf{i}$, pereopod $4 ; \mathbf{j}$, pereopod $5 ; \mathbf{k}$, pleopod $1 ; \mathbf{l}$, pleopod 2 ; No setae shown on most figures. (scale bar $=2 \mathrm{~mm}, \mathbf{a}-\mathbf{c}$ only) 
tl $19.4 \mathrm{~mm}$ ), stn SAHUL 138, Sahul Banks, unnamed shoal $W$ of Mangol Shoal (11 $\left.40.26^{\prime} S, 125^{\circ} 04.84^{\prime} \mathrm{E}\right)$, top of shoal, $18 \mathrm{~m}$, naturalists' dredge, coll. G.C.B. Poore et al. (with Consulting Enviromental Engineers), 26.10.2001.

\section{Diagnosis}

Carapace with dorsal oval $70 \%$ of carapace length; without cardiac prominence; carapace $22 \%$ of total length. Rostrum broadly triangular. Abdominal somite 11.5 times length of abdominal somite 2; somites 3-5 with small inconspicous lateral tufts of setae. Telson tapering from one-third length to rounded distolateral corners, apex truncate, telson as wide as long. Eyestalks with triangular apical lobes; cornea pigmented and domed. Antenna 1 peduncle longer than antenna 2 peduncle.

Maxilliped 3 operculiform, ischium-merus 1.5 times as long as greatest width, not projecting beyond articulation of carpus, without distal spine, with 25 teeth in crista dentata plus rugosity mesial to teeth; carpus and propodus subovate (not expanded); dactylus short and narrow; without exopod. Pereopods 1 (female) equal, similar; ischium finely denticulate on lower margin; merus with straight unarmed lower margin; carpus, propodus and dactylus unarmed; fixed finger with proximal blade ending in distally directed tooth, separated from apex of finger by notch. Pereopod 3 propodus with posteriorly-produced rounded lobe. Female pleopod 1 uniramous, 2-articled. Female pleopod 2 biramous, exopod 2-articled. Pleopods 3-5 with appendix interna little longer than basal width and barely emerging from mesial margin of endopod. Uropod endopod oval, with convex outer margin; exopod subcircular, with rounded distal and inner margins, outer margin freely curved to distal margin.

\section{Description}

Notes additional to diagnosis from female holotype

Rostrum reaching to third length of eyestalks. Carapace with linea thalassinica and dorsal oval well defined. Telson widest at one-third length, as wide as long, convex lateral margins tapering to rounded distolateral corners, distal margin barely truncate.

Eyestalk with symmetrical triangular apical lobe; cornea subdistal, domed. Antenna 1 peduncle with article 33 times as long as article 2, overreaching antenna 2 by about third length of last article. Antenna 2 with minute scaphocerite, article 50.8 length of article 4. Maxilliped 3 without exopod; ischium-merus margins evenly curved, unarmed; propodus as long as carpus, 1.5 times as long as wide, with convex margins; dactylus half as long as propodus, third as broad.

Cheliped ischium with 5 irregular teeth along lower margin; merus with straight lower margin, strongly convex upper margin; width : dorsal length ratios of merus, carpus, palm $-0.70,0.65,0.75$; fixed broad proximally, with concave blade ending in distally directed tooth, separated from apex of finger by notch two-thirds along, 0.65 length of palm. Pereopod 2 width : dorsal length ratios of merus, carpus, propodus - 0.44, 0.60, 1.38 . Pereopod 3 propodus with slight rounded proximal heel, lower margin slightly concave, depth 0.63 greatest dimension.

Female pleopod 1 with article 2 curved, 1.3 times as long as first. Female pleopod 2 with curved basis; exopod article 10.7 times length of basis, article 2 cylindrical, 08 length of first; endopod shorter than exopod. Uropodal endopod reaching further than telson, greatest width 0.6 times greatest length, inner margin evenly curved, upper surface without setae; exopod larger than endopod, greatest width 0.86 length.

\section{Etymology}

For the Sahul Shelf; noun in apposition.

\section{Remarks}

Only the female is known. Poore's (1994) key suggests membership of Biffarius on the basis of maxilliped 3 , the appendix interna, eyes, antennae peduncles, rostrum and telson. However, equal similar chelipeds are not diagnostic of this genus in which the larger cheliped has a prominent meral hook. Equal chelipeds do occur in species of Eucalliax Manning and Felder, 1991 and some species of Callichirus Stimpson, 1866 but maxilliped 3 has one or two expanded distal articles in these genera, a feature not seen in the new species but considered by most authors to be of generic and subfamily significance. Placement in a genus other than Callianassa awaits discovery of the male and a more robust view of callianassid genera.

\section{Family Micheleidae Sakai, 1992}

Micheleinae Sakai, 1992b: 18.

Micheleidae. - Poore, 1994: 99. - Poore, 1997: 354-356.

\section{Remarks}

The Micheleidae are a small family of four genera. Its species are best recognised by the callianassidlike habitus and possession of anterolateral lobes on abdominal somite 1 which interact with the tripartite posterior margin of the carapace. The eyestalks are cylindrical, never flattened. The chelipeds are equal. Pereopods 3 and 4 never have a single distal spiniform seta on the lower margin of the propodus. 


\section{Michelea Kensley and Heard, 1991}

Michelea Kensley and Heard, 1991: 519. - Poore, 1997: 373 .

\section{Remarks}

Michelea, with 11 species, is the most distinctive of all micheleid genera. The pleopods bear unique marginal lamellae, at least on the lateral edge of the endopod but usually on margins of both rami. The species differ in the number of these lamellae, shape of the limbs, especially the uropod, and in the number of gills. The species from the Dampier Archipelago could not be placed using Poore's (1997) key to species. It is closest to M. leura (Poore and Griffin, 1979) and the description and illustrations refer to differences from this more fully described species (see Poore, 1997).

\section{Michelea dampieri sp. nov.}

Figures 6, 7

\section{Material examined}

\section{Holotype}

Western Australia, Dampier Archipelago. WAM C 25920 (male, cl. $3.7 \mathrm{~mm}$, tl. $14.3 \mathrm{~mm}$; stained with chorazol black), stn DA1/98/31, Searipple Passage $\left(20^{\circ} 31.230^{\prime} \mathrm{S}, 116^{\circ} 51.182^{\prime} \mathrm{E}\right)$, intertidal, many hard corals and sponges, some soft coral, sand flat, scattered limestone rock, coll. M. Hewitt et al., 28.10.1998.

\section{Diagnosis}

Gills fully developed. Pleopods $2-5$ with $7 / 3,17 / 5$ and 5/2 marginal lamellae on endopods/exopods respectively. Telson semicircular, length 0.9 width. Maxilliped 3 ischium without crista dentata; merus without mesial tooth.

\section{Description}

Cephalothorax 0.25 total length, about twice as long as greatest depth.; rostrum flat, slightly depressed distally, as long as broad at base, about third as long as eyestalks; cervical groove weakly defined, reaching 0.55 length of cephalothorax; longitudinal setal-row level with lateral margin of eyestalk, of 4 setae; marginal setal-row of 3 setae at base of eyestalk; lateral setal-row of 3 setae.

Abdominal somite 1 with dorsolateral longitudinal setal-row of 6 setae. Abdominal somite 2 with transverse setal-row of about 8 setae near lateral posterior margin; abdominal somites 3-5 with transverse setal-rows of 5-7 setae near midpoint; all somites also with groups of long simple setae, none with marginal setal-rows.

Antenna 1 with elongate waisted article 1 , almost half as long as cephalothorax; articles 2 and 3 subequal, each about 0.2 length of article 1; flagella each of 10 articles, longer than peduncle. Antenna 2 with distinct articulating acicle, about half length of article 2; article 4 reaching to middle of article 2 of antenna 1; article 5 short; flagellum of 20 articles, more than twice as long as peduncle.

Mandible, maxillae, maxillipeds 1 and 2 as in $M$. leura. Maxilliped 3 ischium without crista dentata; merus without mesial tooth.

Chelipeds equal; ischium with weak lower tooth; merus with weak tooth on slightly convex lower margin, upper margin strongly convex, especially proximally; carpus unarmed; propodus almost cylindrical; fixed finger 0.36 length of propodus, its cutting edge with 1 obsolete tooth on proximal half; dactylus cutting edge irregular, curved distally, equal to fixed finger.

Pereopod 2 merus-propodus with lower marginal rows of long setae; carpus 0.63 length of merus; propodus little longer than carpus with setal-row of 7 short setae; fixed finger cutting edge with 4 short spiniform setae; dactylus longer than fixed finger, with 5 short spiniform setae on distal half of cutting edge; each finger with corneous tip. Pereopod 3 propodus twice as long as wide, with 4 spiniform setae on lower margin, plus 2 on distal-lower and 2 on distal-upper mesial face; and 2 transverse setalrows of 4 setae; propodus with setae on lower margin transforming to strongly pectinate distally; dactylus with 1 spiniform seta on upper-mesial margin. Pereopod 4 propodus 2.8 times as long as wide, 4-6 weakly aligned transverse rows of spiniform setae on mesial face, concentrated near margins and strongest on lower margin and distally, and 2 transverse setal-rows of 5 and 3 setae; propodus with setae on lower margin transforming to strongly pectinate distally; dactylus with about 11 spiniform setae in weak rows on upper-mesial margin. Pereopod 5 semichelate; propodus with setae on lower margin transforming to strongly pectinate distally; fixed finger with 5 distal spiniform setae; dactylus with a short spiniform seta on truncate margin and lateral row of 6 short spiniform setae.

Pleopods 1 of male curved mesially, expanded distally, with 8 minute hooks, setose around midpoint and laterally, and with 1 simple seta at apex. Pleopod 2 endopod with probably 7 marginal lamellae laterally; appendix interna sac-like, 3 times as long as wide; appendix masculina 6 times as long as wide, 1.7 times as long as appendix interna, with 8 setae on distal third; exopod with 3 lamellae distolaterally. Pleopods 3 and 4 with 17 lamellae on endopod, 5 on exopod; pleopod 5 with 5 lamellae on endopod, 2 on exopod.

Uropodal endopod ovate, 1.3 times as long as wide, with a minute distal tooth; exopod ovate, 1.7 times as long as wide, mesiodistal oblique, lateral margin with short spiniform setae. Telson length 0.9 times width, almost semicircular. 

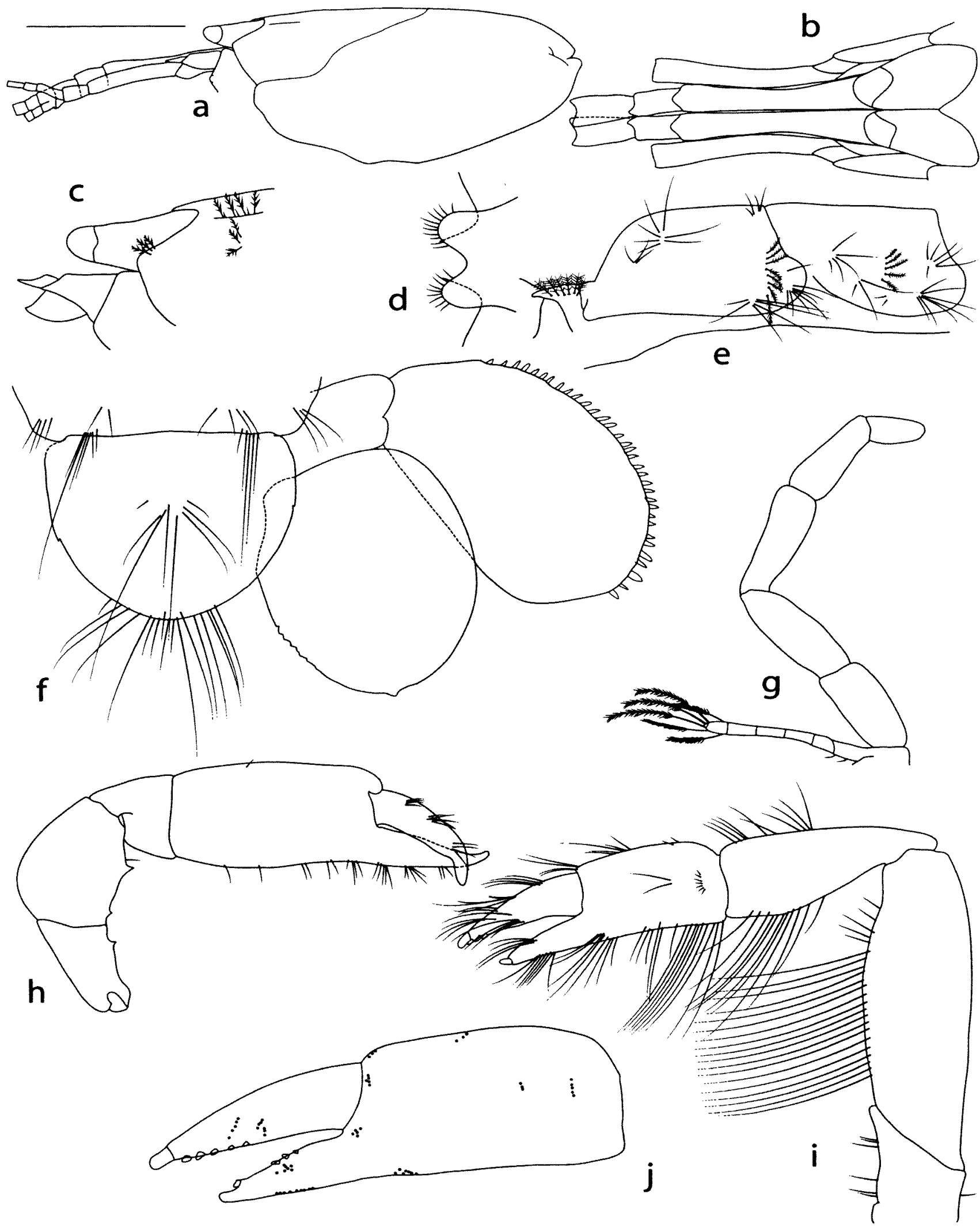

Figure 6 Michelea dampieri sp. nov. Holotype male, WAM C 25920. a, lateral view of carapace, eyes and bases of antennae; $\mathbf{b}$, dorsal view of eyes and bases of antennae; $\mathbf{c}$, anterior lateral carapace and eyes; dorsolateral anterior lobes of abdominal somite 1 overlaying carapace margin; $\mathbf{e}$, abdominal somites 1-3; $\mathbf{f}$, telson and right uropod; $\mathbf{g}$, maxilliped $3 ; \mathbf{h}$, left cheliped; $\mathbf{i}, \mathbf{j}$, pereopod 2 and detail. (scale bar $=2 \mathrm{~mm}, \mathbf{a}, \mathbf{b}$, e only) 


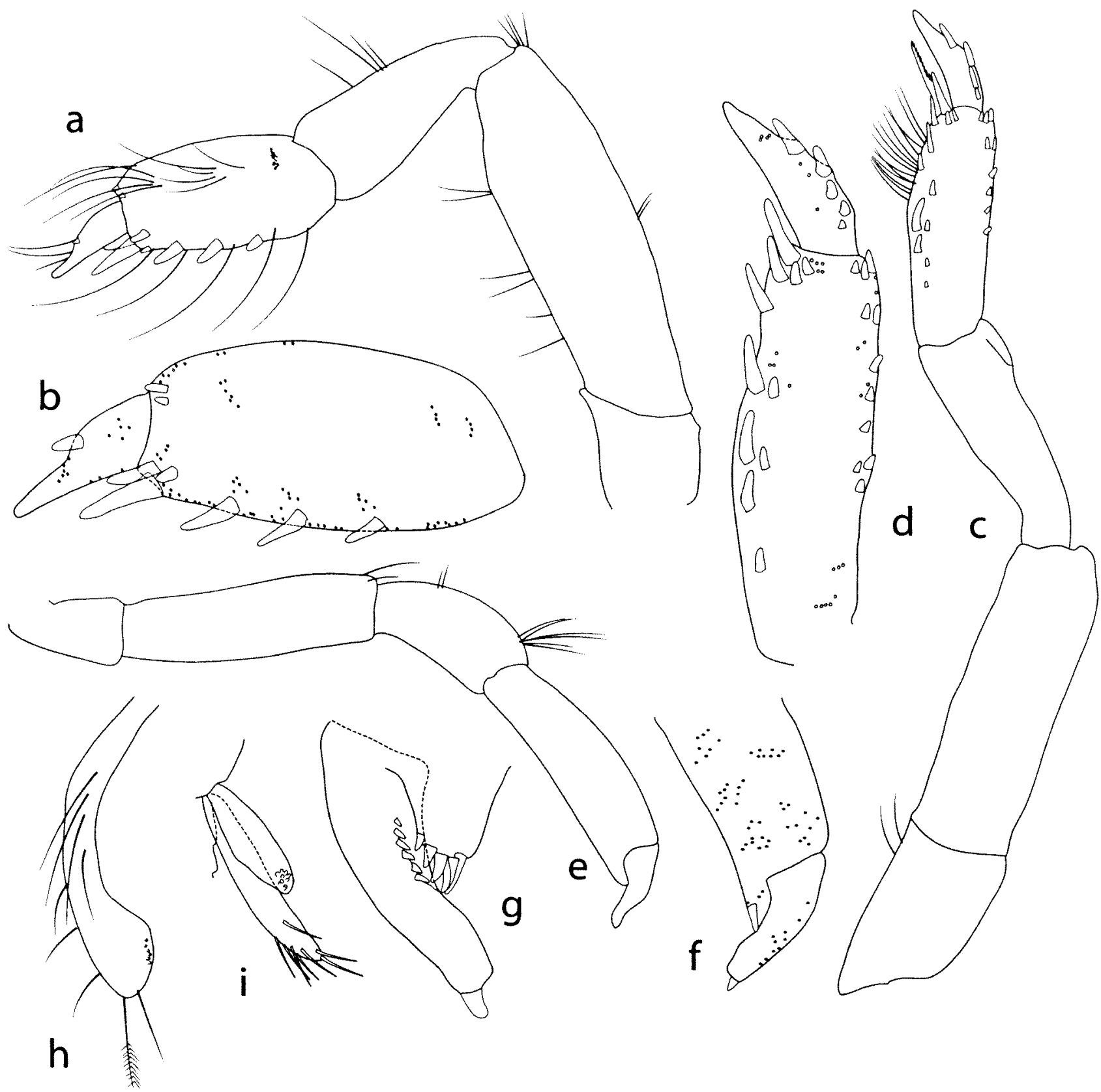

Figure 7 Michelea dampieri sp. nov. Holotype male, WAM C 25920. a, b, pereopod 3 and detail; c, d, pereopod 4 and detail; e, $\mathbf{f}, \mathbf{g}$, pereopod 5 and detail; $\mathbf{h}$, pleopod $1 ; \mathbf{i}$, appendix masculina and appendix interna on pleopod 2.

Branchial formula $(\mathrm{f}=$ filamentous; $r=$ rudimentary): $\begin{array}{lllllllll}\text { Thoracomere } & 1 & 2 & 3 & 4 & 5 & 6 & 7 & 8\end{array}$ Arthrobranch - $\begin{array}{rllllll}\mathrm{r} & 1 & 2 & 2 & 2 & 2 & -\end{array}$ $\begin{array}{lllllllll}\text { Epipod } & 1 & 1 & 1 & 1 & 1 & 1 & 1 & -\end{array}$ Podobranch - - f $f$ f $f$ -

\section{Etymology}

The specific name honours William Dampier (1651-1715), privateer, "profiteer" and Australia's first natural historian, who visited northwestern Australia in 1699 on his second voyage to Australia and published an account of the animals and plants from the region (George, 1999).

\section{Remarks}

Michelea dampieri is the fifth species of the genus known from Australia, all from only one or two examples. The new species has well developed gills and numerous pleopodal lamellae when compared to other species. Its semicircular telson is similar to that in $M$. leura (from the Great Barrier Reef) but has fewer setae in the carapace setal rows, lacks a crista dentata on maxilliped 3, and has fewer spiniform setae on pereopods. Michelea leura is known only from females, $M$. dampieri only from a male. Sex explains the differences between pleopods 1 and 2 of the two species but is unlikely 
to contribute to differences in armature of pereopods. Michelea hortus Poore, 1997, found further south in WA, differs most obviously from the new species in a more tapered telson.

\section{ACKNOWLEDGEMENTS}

I thank Diana Jones and Melissa Hewitt, Western Australian Museum, who facilitated my participation in sampling in the Dampier Archipelago and entrusted the thalassinideans to me for study. I also thank Scott Chidgey, Consulting Environmental Engineers, for the invitation to participate in his survey of the Sahul Shoals. I thank too Peter Dworschak, Vienna, for valuable comments on the manuscript.

\section{REFERENCES}

Davie, P.J.F. (2002). Crustacea: Malacostraca: Phyllocarida, Hoplocarida, Eucarida (Part 1). In Wells, A. and Houston, W.W.K. (eds), Zoological Catalogue of Australia. 19.3A. Melbourne: CSIRO Publishing, Australia. pp. xii, 551.

Dworschak, P.C. (2005). Global diversity of Thallassinidea [sic] (Decapoda): an update (19982004). Nauplius 13: 57-63.

George, A.S. (1999). William Dampier in New Holland: Australia's first natural historian. Bloomings Books, Hawthorn. 171 pp.

Heard, R.W. and Manning, R.B. (1998). A new genus and species of ghost shrimp (Crustacea: Decapoda: Callianassidae) from the Atlantic Ocean. Proceedings of the Biological Society of Washington 111: 883-888.

Heard, R.W. and Manning, R.B. (2000). A new genus and species of ghost shrimp from Tobago, West Indies (Crustacea: Decapoda: Callianassidae). Proceedings of the Biological Society of Washington 113: 70-76.

Jones, D.S. (ed.) (2004). Report on the results of the Western Australian Museum/Woodside Energy Ltd. Partnership to explore the marine biodiversity of the Dampier Archipelago, Western Australia 1998-2002. Records of the Western Australian Museum, Supplement 66: vii-xv, 1-401.

Juarrero, A., García-Debrás, A. and Martinez-Iglesias, J.C. (1997). A new genus and species of Laomediidae (Crustacea: Decapoda: Thalassinidea) in Cuba. Avicennia 6/7: 36-42.

Kensley, B. (1989). New genera in the thalassinidean families Calocarididae and Axiidae (Crustacea: Decapoda). Proceedings of the Biological Society of Washington 102: 960-967.

Kensley, B. (1996a). The genus Paraxiopsis De Man, with descriptions of new species from the Western Atlantic (Crustacea: Decapoda: Axiidae). Bulletin of Marine Science 58: 709-729.

Kensley, B. (1996b). New thalassinidean shrimp from the Pacific Ocean (Crustacea: Decapoda: Axiidae and Calocarididae). Bulletin of Marine Science 59: 469489.

Kensley, B. (2003). Axioid shrimps from Guam
(Crustacea, Decapoda, Thalassinidea). Micronesica 35-36: 359-384.

Kensley, B. and Heard, R.W. (1991). An examination of the shrimp family Callianideidae (Crustacea: Decapoda: Thalassinidea). Proceedings of the Biological Society of Washington 104: 493-537.

Leach, W.E. (1814). Entry: Crustaceology. pp 383-437, pl. 221. In, The Edinburgh Encyclopedia conducted by David Brewster LLD. Vol. 7. Edinburgh.

de Man, J.G. (1888). Bereicht über die von Herrn Dr. J. Brock im indischen Archipel gesammelten Decapoden und Stomatopoden. Archiv für Naturgeschichte 53: 215-600.

de Man, J.G. (1905). Diagnoses of new species of macrurous decapod Crustacea from the "SibogaExpedition". Tijdschrift der Nederlansche Dierkundige Vereeniging 9: 587-614.

de Man, J.G. (1925). The Decapoda of the SibogaExpedition. Part VI. The Axiidae collected by the Siboga-Expedition. Siboga Expéditie 39a5: 1-127.

de Man, J.G. (1928). The Decapoda of the SibogaExpedition. Part 7. The Thalassinidae and Callianassidae collected by the Siboga-Expedition with some remarks on the Laomediidae. Siboga Expéditie Monographie 39a6: 1-187.

Manning, R.B. and Felder, D.L. (1991). Revision of the American Callianassidae (Crustacea: Decapoda: Thalassinidea). Proceedings of the Biological Society of Washington 104: 764-792

Manning, R.B. and Tamaki, A. (1998). A new genus of ghost shrimp from Japan (Crustacea: Decapoda: Callianassidae). Proceedings of the Biological Society of Washington 111: 889-892

Ngoc-Ho, N. (1991). Sur quelques Callianassidae et Upogebiidae de Nouvelle-Calédonie (Crustacea, Thalassinidea). Pp. 281-311, figs 281-211. In Richer de Forges, B. (ed.), Le benthos des fonds meubles des lagons de Nouvelle-Calédonie. ORSTOM Editions: Paris.

Ngoc-Ho, N. (1994). Some Callianassidae and Upogebidae from Australia with description of four new species (Crustacea: Decapoda: Thalassinidea). Memoirs of the Museum of Victoria 54: 51-78.

Ngoc-Ho, N. (1998). Le genre Eutrichocheles WoodMason, 1876 (Crustacea, Decapoda, Thalassinidea) en Polynésie française et au Vietnam avec description de deux espèces nouvelles. Zoosystema 20: 363-378.

Ngoc-Ho, N. (2001). Austinogebia, a new genus in the Upogebiidae and rediagnosis of its close relative, Gebiacantha Ngoc-Ho, 1989 (Crustacea: Decapoda: Thalassinidea). Hydrobiologia 449: 47-58.

Ngoc-Ho, N. (2003). European and Mediterranean Thalassinidea (Crustacea, Decapoda). Zoosystema 25: $439-555$.

Ngoc-Ho, N. (2005). Thalassinidea (Crustacea, Decapoda) from French Polynesia. Zoosystema 27: 47-83.

Ngoc-Ho, N. (2007). Upogebiidae (Decapoda: Thalassinidea) mostly from the Dampier Archipelago, Western Australia. In Jones, D.S. (ed.), Report on the Crustaceans collected during the Woodside Energy Ltd/Western Australian Museum Partnership to explore the Marine Biodiversity of the Dampier 
Archipelago, Western Australia 1998-2002. Records of the Western Australian Museum Supplement 73 : $131-159$.

Poore, G.C.B. (1975). Systematics and distribution of Callianassa (Crustacea, Decapoda, Macrura) from Port Phillip Bay, Australia, with descriptions of two new species. Pacific Science 29: 197-209.

Poore, G.C.B. (1994). A phylogeny of the families of Thalassinidea (Crustacea: Decapoda) with keys to the families and genera. Memoirs of the Museum of Victoria 54: 79-120.

Poore, G.C.B. (1997). A review of the thalassinidean families Callianideidae Kossmann, Micheleidae Sakai, and Thomassiniidae de Saint Laurent (Crustacea: Decapoda) with descriptions of fifteen new species. Zoosystema 19: 345-420.

Poore, G.C.B. (2000). A new genus and species of callianassid ghost shrimp from Kyushu, Japan (Decapoda: Thalassinidea). Journal of Crustacean Biology 20 (Special Issue 2): 150-156.

Poore, G.C.B. and Griffin, D.J.G. (1979). The Thalassinidea (Crustacea: Decapoda) of Australia. Records of the Australian Museum 32: 217-321.

Rathbun, M.J. (1906). The Brachyura and Macrura of the Hawaiian Islands. Bulletin of the United States Fisheries Commission 23: 827-930.

Sakai, K. (1984). Some thalassinideans (Decapoda: Crustacea) from Heron Island, Queensland, eastern Australia, and a new species of Gourretia from East Africa. The Beagle, Occasional Papers of the Northern Territory Museum of Arts and Sciences 1: 95-108.

Sakai, K. (1986). Axiopsis brucei sp. nov., a new spongeinhabiting axiid (Crustacea: Decapoda: Thalassinidea), from north-west Australia. The Beagle, Occasional Papers of the Northern Territory Museum of Arts and Sciences 3: 11-20.

Sakai, K. (1988). A new genus and five new species of Callianassidae (Crustacea: Decapoda: Thalassinidea) from northern Australia. The Beagle, Occasional Papers of the Northern Territory Museum of Arts and Sciences 5: 51-69.

Sakai, K. (1991). On Paracalocaris sagamiensis, a new genus and species of from Japan (Decapoda: Thalassinidea: Axiidae). Proceedings of the Biological Society of Washington 104: 30-39.

Sakai, K. (1992a). Axiid collections of the Zoological Museum, Copenhagen, with the description of one new genus and six new species (Axiidae, Thalassinidea, Crustacea). Zoologica Scripta 21: 157180.

Sakai, K. (1992b). The families Callianideidae and Thalassinidae, with the description of two new subfamilies, one new genus and two new species. Naturalists, Publications of Tokushima Biological Laboratory, Shikoku University 4: 1-33.

Sakai, K. (1994). Eleven species of Australian Axiidae (Crustacea: Decapoda: Thalassinidea) with descriptions of one new genus and five new species. The Beagle, Occasional Papers of the Northern Territory Museum of Arts and Sciences 11: 175-202.
Sakai, K. (1999a). Synopsis of the family Callianassidae, with keys to subfamilies, genera and species, and the description of new taxa (Crustacea: Decapoda: Thalassinidea). Zoologische Verhandelingen, Leiden 326: $1-152$.

Sakai, K. (1999b). Redescription of Ctenocheles balssi Kishinouye, 1926, with comments on its systematic position and establishment of a new subfamily Gourretiinae (Decapoda, Callianassidae). Crustaceana 72: 85-97.

Sakai, K. (2002). Callianassidae (Decapoda, Thalassinidea) in the Andaman Sea, Thailand. Phuket Marine Biological Center Special Publication 23: 461532.

Sakai, K. (2004a). A curious taxonomy of the common Japanese callianassids by Tamaki. A rebuttal. Crustaceana 77: 113-124.

Sakai, K. (2004b). Dr. R. Plante's collection of the families Callianassidae and Gourretiidae (Decapoda, Thalassinidea) from Madagascar, with the description of two new genera and one new species of the Gourretiidae Sakai, 1999 (new status) and two new species of the Callianassidae Dana, 1852. Crustaceana 77: 553-602.

Sakai, K. and Ohta, S. (2005). Some thalassinid collections by R/V "Hakuhou-Maru" and R/V "Tansei-Maru", University of Tokyo, in the Sulu Sea, Philippines, and in Sagami Bay and Suruga Bay, Japan, including two new species, one new genus, and one new family (Decapoda, Thalassinidea). Crustaceana 78: 67-93.

Sakai, K. and de Saint Laurent, M. (1989). A check list of Axiidae (Decapoda, Crustacea, Thalassinidea, Anomula), with remarks and in addition descriptions of one new subfamily, eleven new genera and two new species. Naturalists, Publications of Tokushima Biological Laboratory, Shikoku University 3: 1-104.

Sakai, K. and Türkay, M. (1999). A new subfamily, Bathycalliacinae n. subfam., for Bathycalliax geomar n. gen., n. sp., from deep water cold seeps off Oregon, USA. Senckenbergiana Biologica 79: 203-209.

Stimpson, W. (1866). Descriptions of new genera and species of macrurous Crustacea from the coasts of North America. Proceedings of the Chicago Academy of Science 1: 46-68.

Tirmizi, N.M. (1983). Four axiids (Decapoda, Thalassinidea) from Indonesia. Researches on Crustacea, Carcinological Society of Japan 12: 85-95.

Tudge, C.C., Poore, G.C.B. and Lemaitre, R. (2000). Preliminary phylogenetic analysis of generic relationships within the Callianassidae and Ctenochelidae (Decapoda: Thalassinidea: Callianassoidea). Journal of Crustacean Biology 20 (Special Issue 2): 129-149.

Türkay, M. and Sakai, K. (1995). Decapod crustaceans from a volcanic hot spring in the Marianas. Senckenbergiana Maritima 26: 25-35.

Williams, A.B. (1993). Mud shrimps, Upogebiidae, from Western Atlantic (Crustacea: Decapoda: Thalassinidea). Smithsonian Contributions to Zoology 544: $1-77$.

Wood-Mason, J. (1876). On the Astacus modestus of Herbst. Annals and Magazine of Natural History (4) 17: 264 . 